\title{
Construction of 3D geological models in glacial deposits to characterise migration of pollution
}

\author{
Knud E.S. Klint, Frants von Platen-Hallermund and Mette Christophersen
}

The National geological database at the Geological Survey of Denmark and Greenland (GEUS) is based on an extensive well database Jupiter, a geophysical database Gerda (Tulstrup 2003) and a recently established database for various types of geological models. These databases are integrated in a GIS system. The integration of this data enables new possibilities of constructing improved geological models. GIS systems offer a powerful tool for the geologist not only in combining multiple data, but also in visualising the model and hence presenting the final product in a simple and understandable way. 3D geological models will become increasingly important for the execution of improved cost-benefit analysis and risk assessment of contaminated sites, as well as strategic evaluation of groundwater and raw material resources in general. The possibility of storing such models on a public platform will be a major advance for future users of geological databases.

The primary goal of this paper is to demonstrate the potential of an integrated GIS system, with an example of how traditional geological information may be combined in new ways in order to improve the correlation of well data in multiple directions. The application is demonstrated for a highly contaminated industrial site in the town of Ringe, Denmark (Fig. 1).

\section{Data analysis}

Basically two methods exist for constructing 3D models from borehole data. Using the vertical approach, information from the nearest boreholes is projected onto an array of vertical sections (Fig. 2), thus guiding the drawing of lines separating the interpreted units. The boundaries separating the geological units from all cross-sections are then converted into a 3D surface through interpolation. Using the horizontal approach, information from all boreholes is projected onto an array of horizontal sections covering the relevant area (Fig. 3). The

Fig. 1. Location of the former tar and asphalt factory in Ringe (RTA site) with the distribution of wells inside the source area and in a wider zone around the site. The site is situated on map sheet 155, and all well numbers have the prefix '155.' in the Jupiter well database. Vertical section A-B shown in Fig. 2; a horizontal slice diagram and 3D model are shown in Figs 3-4.
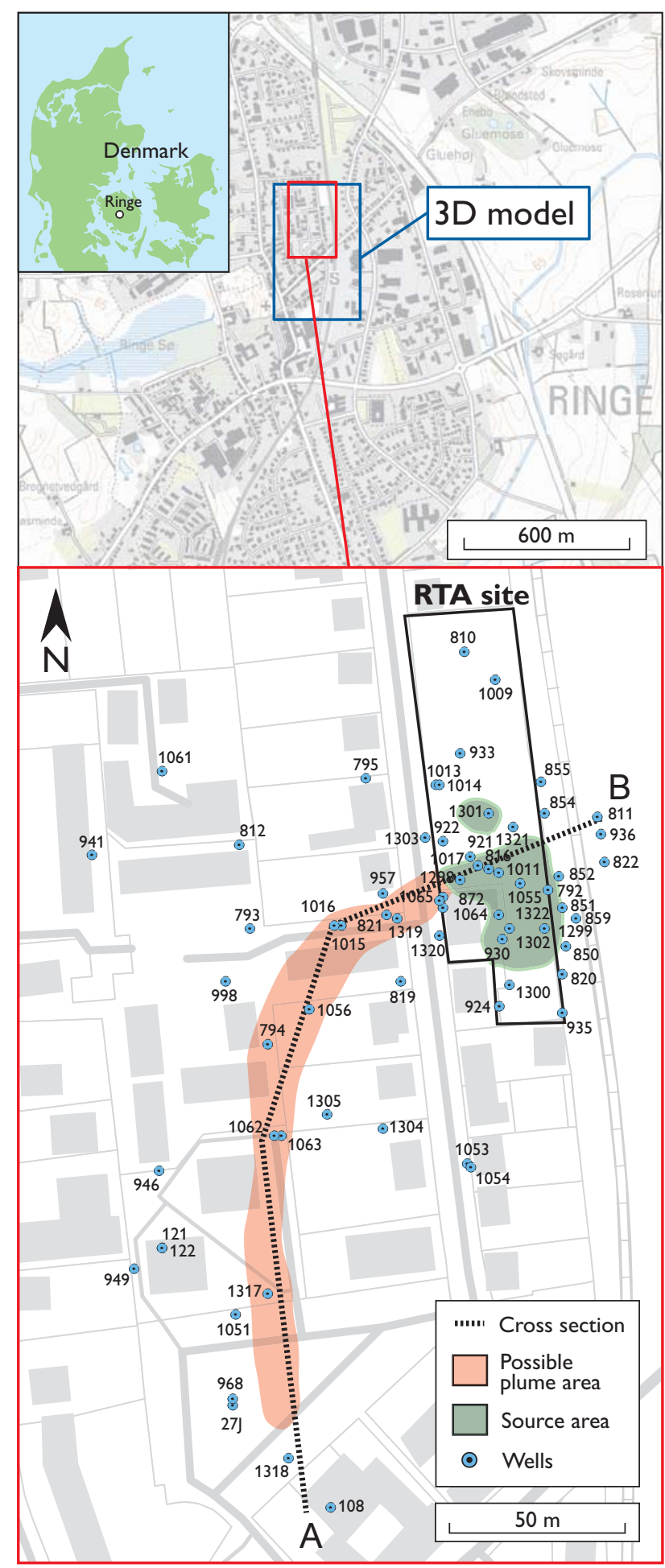


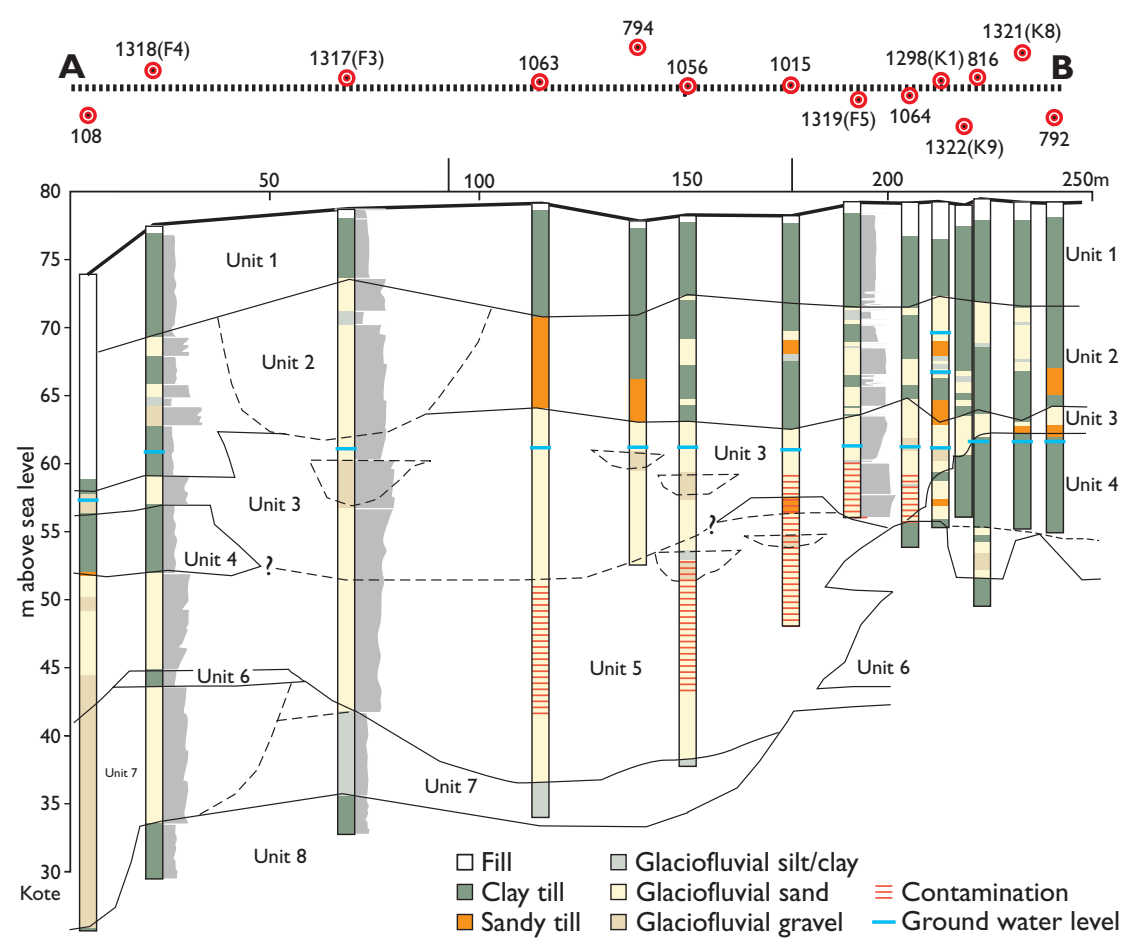

Fig. 2. Vertical correlation approach. Crosssection A-B (Fig. 1) showing the distribution of the eight primary geological units. Three new wells display grain size distributions in grey shading. All well numbers are prefixed '155.'.

distance between the sections is determined by the geological complexity. The lithological and hydraulic information from the boreholes penetrating the sections is used to guide drawing of unit boundaries at the relevant level. Finally, the 3D model is constructed by stacking all the horizontal sections (Fig. 4).

In this study both methods are used, but with emphasis on the horizontal sections because current knowledge of the glaciodynamic history and position of the local geological
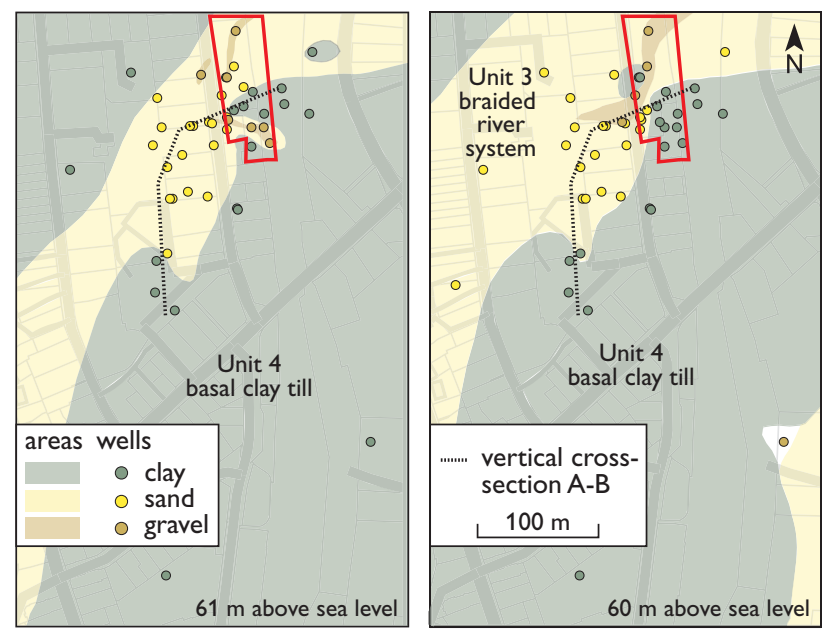

Fig. 3. Horizontal correlation approach. Slice diagram showing the distribution of clay, sand and gravel in wells at two depth intervals. Red frame indicates location of the Ringe tar and asphalt factory site. Position of section A-B in Fig. 2 is indicated. units are better utilised in this way. A general geomorphological analysis and thorough description of the depositional environment is included in the interpretation of the different geological units in the area (Klint \& von Platen-Hallermund 2006). Database procedures for extracting borehole data from a series of horizons, as well as GIS procedures for producing a collection of maps based on borehole information or interpreted unit boundaries in the same intervals have been developed as a tool for the construction of improved geological models. The 3D display of the GIS system is used for viewing the final model.

\section{Site history}

The Ringe tar and asphalt factory site (RTA site) is located in the centre of Ringe (Fig. 1). Asphalt and creosote production took place from 1929 to 1962 , and during that period storage tanks were placed all over the area. In 1987 it was discovered that the factory site subsurface was strongly contaminated with creosote, and in 1988 remediation of the site was commenced. Old buildings and storage tanks were removed and some of the most heavily contaminated soil was excavated and removed. The site has been used extensively for contamination investigations for several years (e.g. Broholm et al. 2000; Klint \& Tsakiroglou 2000). A large number of wells have been drilled during these projects, and four open pits were excavated. 


\section{Geological framework}

The Ringe tar and asphalt factory site is situated on top of an elongated hill approximately $80 \mathrm{~m}$ above sea level. Several small hills and depressions without runoff indicate that the sediments in the hilly area were probably deposited from a stagnating glacier (dead-ice relief) and overridden during a later ice advance. During the earlier research projects a local geological model was established for the upper $22 \mathrm{~m}$ of the Ringe site (Sidle et al. 1998, Nilsson et al. 2001). The investigations showed that the site is dominated by sediments deposited during the Late Weichselian Glaciation 25000 11500 years ago. During 2005 nine wells were drilled in the source area to $c .20 \mathrm{~m}$ below ground surface, and five deep wells were drilled downstream for locating the contamination plume (Fig. 2). The wells were described in terms of matrix texture, structures, colour, fractures, consolidation and contamination. Hydraulic tests and groundwater table measurements in both secondary and primary aquifers supported the interpretation of the depositional environment. The conceptual geological model is well constrained near the surface, but becomes more speculative at greater depth due to the decreasing amount of well data. The eight geological units described below were deduced from the cross-sections and log descriptions (Fig. 2), and slice diagrams produced with a $1 \mathrm{~m}$ interval from 26 to $80 \mathrm{~m}$ above sea level (Fig 3). Finally, a 3D geological model was constructed to outline the spatial distribution of the geological units (Fig. 4).

Unit 1 is basal till. The upper $4-8 \mathrm{~m}$ are dominated by a continuous, massive, undulating ground moraine with occasional minor sand lenses which covers most of the area. This till may be classified as a basal till deposited below a glacier that transgressed the area from the east-south-east during the c. 16 kyr Young Baltic Ice advance (Nilsson et al. 2001; Houmark-Nielsen \& Kjær 2003). The till is penetrated by fractures, and there is generally good hydraulic contact to the underlying beds through the fracture network and embedded sand lenses.

Unit 2 comprises mixed fluvial and diamict deposits. From 4-16 m below the ground surface, a heterogeneous glacial complex dominated by glaciofluvial silty, sandy and gravelly deposits is interbedded with clayey and sandy diamict sediments. The sediments are partly deformed by glaciotectonic processes, and isolated sand lenses form small secondary water reservoirs especially in the central part of the RTA site, at $c$. 8-9 m below ground surface. Other lenses are unsaturated and hence in hydraulic contact with the primary aquifer. Approximately $12 \mathrm{~m}$ below ground surface a more widespread, 3-4 $\mathrm{m}$ thick layer of unconsolidated clayey till covers most of the area, though it may be mixed with larger sand bodies in places. The till is fractured locally and contains numerous thin sand lenses. It is classified predominantly as flow till. The general topography in the area includes several small depressions with the characteristics of dead-ice holes, and the whole unit is interpreted to represent a dead-ice landscape overridden by a glacier.

Unit 3 consists of braided river valley deposits. Between 14-21 m depth a widespread sand/gravel layer 2-7 m thick covers most of the area and probably represents a braided river system with minor channels eroded into an underlying ground moraine. The channels are generally dominated by coarse glaciofluvial sand/gravel and boulders. Unit 3 truncates the underlying clay till (Unit 4) locally, thus creating a good hydraulic contact with a major sandy aquifer below, which dominates the western and northern parts of the site (Unit 5). Unit 3 is partly saturated, as the water table is here located approximately $18 \mathrm{~m}$ below ground surface. Accordingly, the deepest, saturated parts of the channels act as hydraulic avenues for infiltration of groundwater and contaminants from the upper units. The general groundwater and contamination flow is directed towards the west-south-west at the RTA site, but turns southwards approximately $30 \mathrm{~m}$ west of the site, thus indicating preferential flow controlled by channels (Fig. 1).

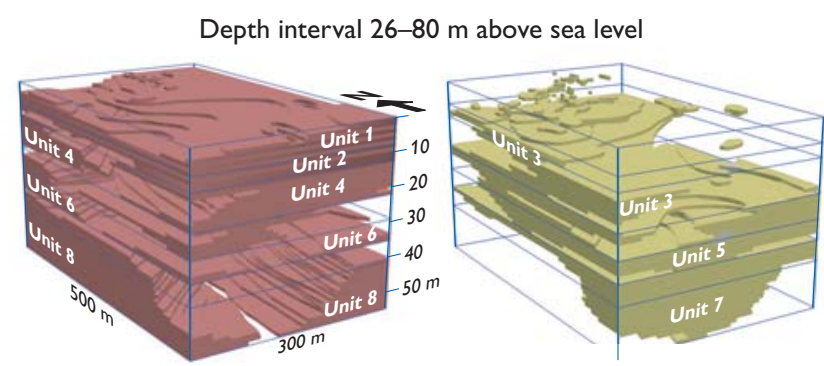

Depth interval 26-61 $\mathrm{m}$ above sea level

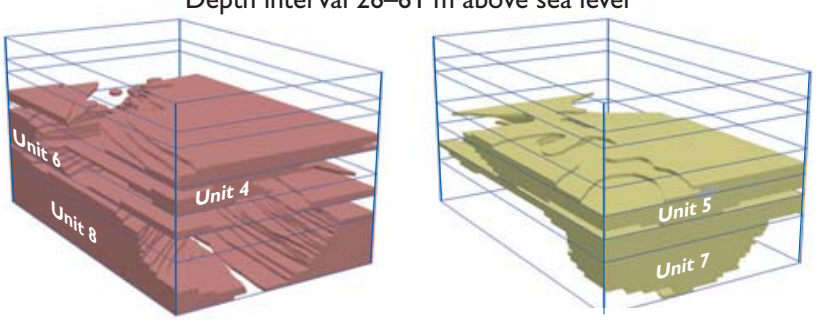

Depth interval $26-40 \mathrm{~m}$ above sea level
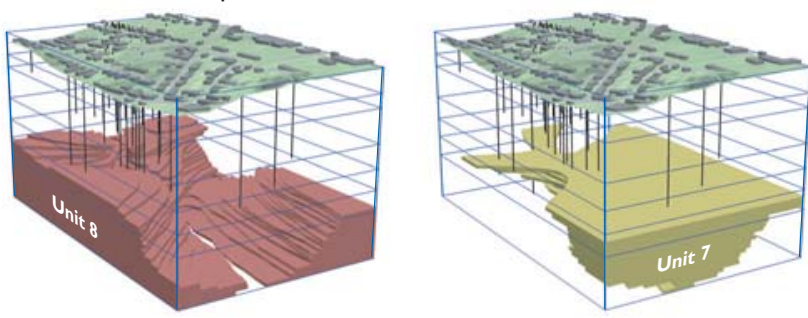

Fig. 4. 3D geological model of the Ringe site showing the distribution of clayey deposits (left) and sandy deposits (right) at different depth intervals (note vertical exaggeration). Ground surface with buildings and position of wells shown in lower model. 
Unit 4 is basal till. A massive basal till $4-8 \mathrm{~m}$ thick covers most of the south-eastern area 17-22 m below ground surface. Its surface is situated above groundwater level in some areas. It is completely eroded by Unit 3 just west of the RTA site, where Unit 3 is resting directly on Unit 5 (Fig. 3).

Unit 5 consists of sandy and silty melt-water river deposits. Unit 5 constitutes a more widely distributed occurrence of glaciofluvial sand, occurring between $24-45 \mathrm{~m}$ depth, with a generally finer grain size than Unit 3 . The sand becomes very fine in the lowest parts, and is dominated by glaciofluvial silt and clay below $37-40 \mathrm{~m}$ depth. Unit 5 is deeply incised into the underlying units, and is thought to represent a well-defined river valley filled with generally finer material than Unit 3. The contaminant plume seems to follow this unit in a narrow south-directed fan.

Unit 6 is clay till. A thin clay till unit locally separates the two sandy units 5 and 7 (Fig 4). This unit probably represents erosional remnants of a previously more widespread clay till unit located 33-36 m below ground surface. The lithological and structural information is, however, sparse and any interpretation of its origin is therefore highly speculative.

Unit 7 comprises river valley deposits. At least $14 \mathrm{~m}$ of sand and gravel have been encountered in wells 155.108 and 155.1318 between $35-49 \mathrm{~m}$ below ground surface (Fig. 2). The water-supply well 155.108 has produced $45 \mathrm{~m} 3$ of water per hour and is considered to be located within an extensive sand/gravel body representing a major buried river valley incised in the clay till of Unit 8. Well 155.1318 has much smaller capacity and hence must be related to a somehow smaller sand reservoir although hydraulically connected to 155.108 .

Unit 8 is basal till. Generally little information exists on the lowest clay till unit below $40 \mathrm{~m}$ depth. The till is generally massive and well consolidated, with a medium to high content of boulders. It has the nature and appearance of a basal till and is locally more than $10 \mathrm{~m}$ thick. Only six wells reach this unit, and its distribution is consequently largely unknown.

\section{Conclusions}

The combination of correlating multiple geological horizontal sections with traditional vertical geological cross-sections using GIS has facilitated the construction of a detailed 3D geological model of the contaminated tar and asphalt factory site in Ringe, which outlines the spatial distribution of primarily sandy and clayey sediments. Detailed descriptions of the sediment properties were used to interpret the depositional processes and hence the depositional environment. This interpretation was included in the separation of the different deposits into units related to distinct glacial environments. The model will be used for assessing the risk of polluting nearby groundwater reservoirs and for designing an optimal remediation programme.

\section{Acknowledgements}

The work was financed by Fyns Amt and carried out in cooperation with Orbicon.

\section{References}

Broholm, M.M., Rügge, K., Tuxen, N., Mosbæk, H. \& Bjerg, P.L. 2000: Migration and degradation of pesticides in an aerobic groundwater aquifer: field injection experiments. In: Bjerg, P.L., Engesgaard, P. \& Krom, T.D. (eds): Proceedings of the International Conference on Groundwater Research, Copenhagen, Denmark, 6-8 June, 2000, 169-170. Rotterdam: Balkema.

Houmark-Nielsen, M. \& Kjær, K.H. 2003: Southwest Scandinavia, 40-15 kyr BP: palaeogeography and environmental changes. Journal of Quaternary Science 18, 765-786.

Klint, K.E.S. \& Tsakiroglou, C.D. 2000: A new method of fracture aperture characterisation. In: Tsihrintzis, V.A. et al. (eds): Proceedings of the 5th International Conference on Restoration and Protection of the Environment 1, Thassos, Greece, 3-6 July, 2000, 127-136.

Klint, K.E.S. \& von Platen-Hallermund, F. 2006: Geologisk model af RTAgrunden ved Villavej i Ringe. En 3-D geologisk model af kildeområde og faneområde ved den tidligere Ringe Tjære Asfalt fabrik på Villavej i Ringe. Danmarks og Grønlands Geologiske Undersøgelse Rapport 2006/9, 18 pp.

Nilsson, B., Sidle, R.C., Klint, K.E.S., Bøggild, C.E. \& Broholm, K. 2001: Mass transport and scale-dependent hydraulic tests in a heterogeneous glacial till - sandy aquifer system. Journal of Hydrology 243 , $162-179$

Sidle, R.C., Nilsson, B., Hansen, M. \& Fredericia, J. 1998: Spatially varying hydraulic and solute transport characteristics of a fractured till determined by field tracer tests, Funen, Denmark. Water Resources Research 34, 2515-2527.

Tulstrup, J. 2003: Environmental data and the Internet: openness and digital data management. Geological Survey of Denmark and Greenland Bulletin 4, 45-48.

\footnotetext{
Authors' addresses

K.E.S.K. \& F.v.P.-H., Geological Survey of Denmark and Greenland, Øster Voldgade 10, DK-1350 Copenhagen K, Denmark, E-mail: kesk@geus.dk M.C., Fyns Amt, Ørbakvej 100, DK-5220 Odense SØ, Denmark.
} 